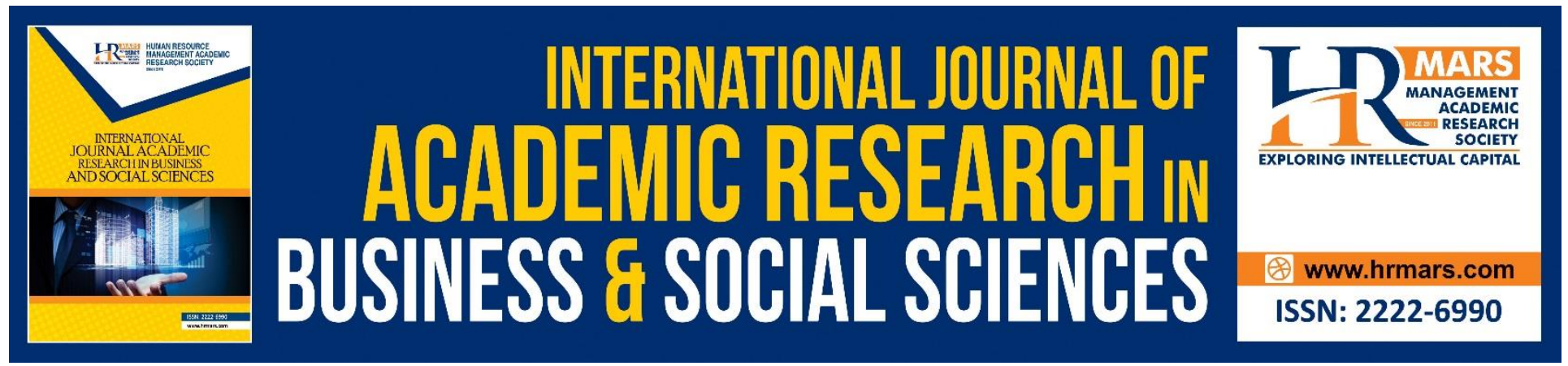

\title{
Influence of Characteristics of Management Accounting Information Systems to Managerial Performance with Variables of Business Strategy Modernations and Uncertainty Duties in Banking Companies in Aceh Province
}

Azzumar, Fazli Syam, Zuraida

To Link this Article: http://dx.doi.org/10.6007/IJARBSS/v8-i7/4339

DOI: $\quad 10.6007 /$ IJARBSS/v8-i7/4339

Received: 26 June 2018, Revised: 19 July 2018, Accepted: 29 July 2018

Published Online: 30 July 2018

In-Text Citation: (Azzumar, Syam, \& Zuraida, 2018)

To Cite this Article: Azzumar, Syam, F., \& Zuraida. (2018). Influence of Characteristics of Management Accounting Information Systems to Managerial Performance with Variables of Business Strategy Modernations and Uncertainty Duties in Banking Companies in Aceh Province. International Journal of Academic Research in Business and Social Sciences, 8(7), 238-256.

Copyright: (C) 2018 The Author(s)

Published by Human Resource Management Academic Research Society (www.hrmars.com)

This article is published under the Creative Commons Attribution (CC BY 4.0) license. Anyone may reproduce, distribute, translate and create derivative works of this article (for both commercial and non-commercial purposes), subject to full attribution to the original publication and authors. The full terms of this license may be seen at: http://creativecommons.org/licences/by/4.0/legalcode

Vol. 8, No. 7, July 2018, Pg. 238 - 256 


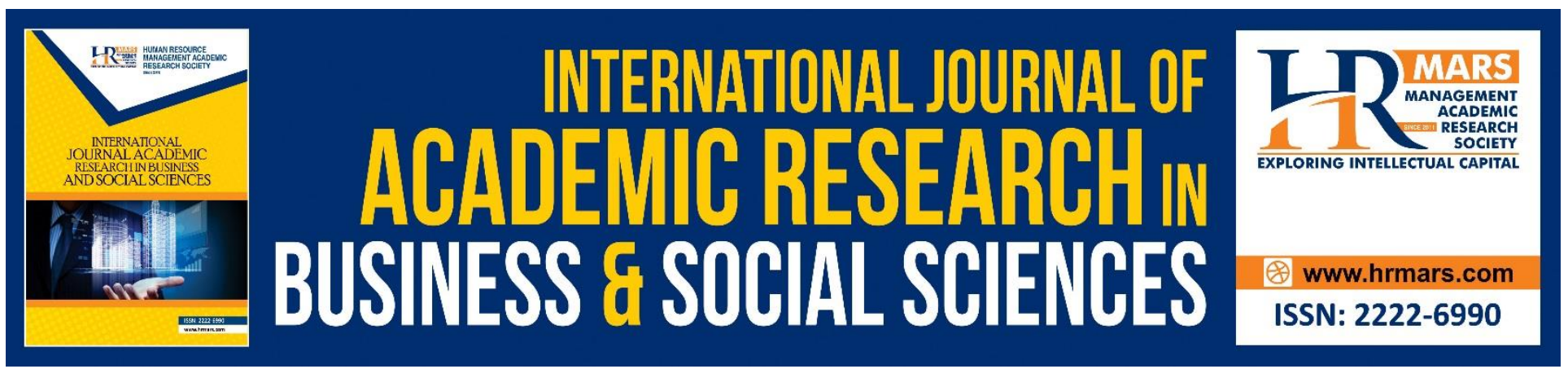

\title{
Influence of Characteristics of Management Accounting Information Systems to Managerial Performance with Variables of Business Strategy Modernations and Uncertainty Duties in Banking Companies in Aceh Province
}

\author{
Azzumar, Fazli Syam, Zuraida \\ Magister Akuntansi Program Pascasarjana Universitas Syiah Kuala Banda Aceh \\ Fakultas Ekonomi Universitas Syiah Kuala Banda Aceh
}

\section{Abstract}

The purpose of this study is to examine the influence of management accounting information system characteristics to managerial performance with business strategy moderation variable and task uncertainty in banking companies in Aceh Province. Sampling in this study was taken as many as $50 \%$ of the total population of 241 by using the method of "Simple Random Sampling" to obtain a sample of 120 respondents. The results showed that the characteristics of management accounting information system have positive and significant influence to managerial performance. Business strategy has a significant and positive effect on managerial performance. Task uncertainty has a significant and negative effect on managerial performance. The interaction of management accounting information system characteristics with business strategy has a significant and positive effect on managerial performance. The interaction between information management accounting system characteristics with task uncertainty has a significant and positive effect on managerial performance.

Keywords: Bank Managerial Performance

\section{PENDAHULUAN}

Aceh's economic growth during the year of 2016 was $3.31 \%$ or an increase from $0.73 \%$ (yoy) in contraction, while Aceh's economy grew by $4.30 \%$ (yoy) in Q4 / 2016, compared with the previous quarter which only reached $2.52 \%$ (yoy). The growth in 2016 is in line with Bank Indonesia's projection of $2.40 \%$ (yoy) $-3.40 \%$ (yoy). Economic performance in 2016 that grew by $3.31 \%$ (yoy) is Aceh's highest performance performance since last 3 years. Nevertheless, the Aceh Provincial Government's revenue performance in the fourth quarter of 2016 recorded a decrease compared to the realization in the same period of the previous year. The decrease in the realization of such revenues is sourced 
INTERNATIONAL JOURNAL OF ACADEMIC RESEARCH IN BUSINESS AND SOCIAL SCIENCES Vol. 8, No. 7, July 2018, E-ISSN: 2222-6990 @ 2018 HRMARS

from other legitimate income. Realized revenues in the fourth quarter of 2016 reached $97.72 \%$ of the target revenue of APDB, while in the same period the previous year reached $97.81 \%$. This is in line with the realization performance of Aceh Provincial Government spending in quarter IV-2016 recorded decreased compared to the realization in the same period the previous year. The realization of expenditure managed by the provincial government is Rp 12,750.27 Billion or $99.03 \%$ of the annual APBD target of Rp 12,874.63 Billion, lower than the same period in the previous year with realization reaching $\mathrm{Rp} 12,638.92$ Billion or $99,13 \%$ of the APBD target of $\mathrm{Rp} 12,749.67$. Economic conditions, politics, security, competition is so global and compete is a factor that is very important to be considered by the management in running the company especially in the banking sector. Therefore, in order to maintain the continuity of its business, the Banks are competing to increase the Bank's source of funds which is then redistributed in the form of credit. To further strengthen and reinforce the legality of the banking business, the government has enacted Law No.7 of 1992 which was later revised with Act No.10 of 1998 on banking. The purpose of this banking law is to realize a healthy banking business, reliable and make the Bank able to face global competition, and with banking institutions will be better in facing the challenges in the future. The definition of the Bank pursuant to Law No.10 of 1998 is: Bank is a business entity that engrunk funds from society in the form of deposits and channel again to the community in the form of credit or in other forms in order to improve the standard of living in many communities.

Availability of adequate accounting management information systems, encouraging accountability and transparency of financial information. Thus, it will reduce conflicts within the organization (Abernethy \& Vagnoni, 2004). Good management accounting information system design is determined by the ability of management in identifying the information needed in the management process to achieve organizational goals. Each organization and business unit has the need for different accounting management information systems, in accordance with the conditions of the organization and business units. Azhar Susanto (2008: 11) states the better the quality of information then the better the quality of communication within an organization so that the better the integrity of the organization. Furthermore, quality information will also enhance the quality of understanding of organizational managers in view of changes that occur both within and outside the organization so that it will quickly and accurately respond to changes that arise.

Characteristics of management accounting information systems can be divided into four parts, namely broadscope (scope), timeliness (timely), aggregation (aggregation), and integration (integration). Broadscope is information with wide and complete coverage. In decentralized organizations, managers need broadscope information as one implication of increased authority, responsibility, and control functions so that managers' needs for information can be met. timeliness where the value of a financial statement will be reduced if the report is not available on time. aggregation (aggregation) is a summary of information according to function, time period and decision model, the higher the level of aggregation of an information it will be less time required to evaluate it, thereby improving the efficiency of management work. integration (integration) is the coordination between the segments of sub-units and between sub-units. The complexity and interdependence of sub-units will be reflected in the integrated information of the management accounting system. This is important when managers are faced with situations in which decisions must be made that will impact some sections.

Management accounting information systems have a very close relationship with the strategic management system. Management accounting information systems have a very important role in strategic management. Some examples of management accounting information systems 
outputs that play an important role in strategic management are: (1) Balanced Score-Card designed to assist managers in evaluating implementation strategies (Kaplan \& Norton, 1996), (2) strategic variance / profitability analysis, tools for analyzing budgetary aberrations and profit realization in a strategic business unit (Shank and Govindarajan, 1995), (3) profit-linked performance measurement systems, is a model used to measure the effect of productivity on earnings over time in a business unit strategic (4) Activity-based Management is a management-oriented management system that enhances customer value (Blocher, 2004; Hansen \& Mowen, 2007)

The use of variables in the company's business strategy because the companies that follow different strategies will shape the characteristics of different information, so that the compatibility between business strategy and information needs of companies is expected to improve managerial performance (Lakshman and Muslichah, 2002). The difference of strategy resulted in the need for information within the company, so it is suspected that business strategy will affect the relationship between management accounting information system characteristics with managerial

\section{Performance}

Performance is a condition that must be known and informed to certain parties to know the level of achievement of an agency results associated with the vision of an organization and know the positive and negative impact of an operational policy taken. Ultimately performance is a management tool for assessing and seeing progress achieved over time or within a certain time frame. Performance can be divided into two, namely corporate performance and managerial performance. Managerial performance is one of the factors that can improve the effectiveness of organizational performance. According to Mahoney et al. (1963), managerial performance is the performance of individual organizational members in managerial activities such as planning, investigation, coordination, evaluation, supervision, staffing, negotiation, and representation.

Mulyadi (2001), conceptual framework of managerial performance (framework of managerial performance) framework is a structure of the components that shape the performance of people who hold managerial positions. Mulyadi (2001) in the conceptual framework of managerial performance framework defines dimensions consisting of: (1) Managerial Skills, (2) Mission, Vision, Core Values, (3) Core Beliefs and (4) Value-Adding Roles .

Banking performance improvement is an effort for every leader of the company, especially banking institutions. Efforts should be made, from planning to each activity to be implemented, to the supervision of all that aims for each activity can be implemented properly. All this with the aim to improve organizational performance.

After the aftermath of the earthquake that hit Aceh province in 2004 and banking companies growing and has its own characteristics to attract consumers. Aceh is currently a tourist city in great demand of tourists demanding the company must have a strong business strategy foundation considering the growing number of banks are also growing in both the strategy and the performance of the company. Another reason the selection of this study was conducted in the banking sector is, the banking company is a financial institution that is quite unique and has a complex work capacity ranging from the process of attracting money to the distribution of money to the community. This led to the tendency of the financial institutions to require high, detailed, and more complex accounting management information.

Mia (1993) states the design of a management accounting system should be able to provide support to managers in making decisions. This is in line with the contingency approach that the level of availability of each of the characteristics of an accounting information system may not always be 
INTERNATIONAL JOURNAL OF ACADEMIC RESEARCH IN BUSINESS AND SOCIAL SCIENCES Vol. 8, No. 7, July 2018, E-ISSN: 2222-6990 @ 2018 HRMARS

the same for every organization but there are certain other factors that will affect the level of need for management accounting information.

Research on the importance of management accounting information systems associated with moderating variables and managerial performance performed by (Gul, 1991; Mia, 1993; Gul and Chia, 1995; Chang, 2003; Solechan, 2009; Yuristisia, 2011) mentions that the characteristics of accounting information management influence on managerial performance, while the relationship between management accounting system characteristics with business strategy, and environmental uncertainty also affect the managerial performance.

This research is a replica of Yuristisia research (2011) but in this research there is addition of one moderating variable that is task uncertainty. The use of variable task uncertainty because according to Tjahjono (2008) job uncertainty is an important variable that can affect the performance of information systems. The higher the degree of task uncertainty, someone will be difficult to work well. Conversely, the lower the degree of uncertainty of a person's tasks will be easier in carrying out activities and the easier it is to improve their performance.

\section{Characteristics of Management Accounting Information Systems}

Management accounting information system is an information system that produces output (output) by using input (input) and process it to achieve specific goals management (Hansen and Mowen 2011). Processing process is the core of an accounting information system and is used to convert inputs into outputs that meet the goals of a system.

Godono, (2011: 179), traditionally, the design of a management accounting system is limited to historical internal information that is historically oriented. However, the increased role of management accounting to assist managers in direction and problem solving has resulted in a change from the management accounting system to include external and non-financial data and futureoriented information. Chenhall and Morris (2011) mentioned that the characteristics of management accounting information system consists of information broadscop, timeliness, aggregation and integration. Bottom of Form

a. Broadscope

SAM broadscope information includes information related to the economy (such as total sales, market share and gross national product) rather than economy (technological progress, social change, demographic development), quantitative rather than quantitative, relating to the external environment organization and provide information pertaining to predictions about possible future events in the future. This broadscope information includes dimensions of focus, time horizon and quantification (Fazli, 2006: 7). Broadscope is information that has wide and complete coverage, which usually includes economic aspects (market share, gross domestic product, total sales and noneconomic aspects such as technological advances, sociological change, demography (Chia 1995, Nazarudin, 1998).

Robbins (2013: 110) in carrying out his duties managers need information from various sources of a broad nature. Therefore, according to Chia (1995) managers need information that has a wide and complete coverage (completeness) which usually includes economic aspects (market share, gross domestic product (GDP), total sales) and non-economic aspects such as technological advances, sociology changes, demographic The broad scope information provided by SAM provides managers with various alternative solutions for consideration. This allows managers to better understand the problem (Chenhall \& Morris 2011).

b. Timeliness 
INTERNATIONAL JOURNAL OF ACADEMIC RESEARCH IN BUSINESS AND SOCIAL SCIENCES Vol. 8, No. 7, July 2018, E-ISSN: 2222-6990 @ 2018 HRMARS

The ability of managers to respond appropriately to an event may be influenced by the timeliness of the management accounting system. Timeliness information enhances the facilities of the management accounting system to report on the latest events and to provide quick feedback on the decisions that have been made. So timeliness includes the frequency of reporting and reporting speed. Timeliness shows the frequency and speed of the report used IAI (2011: 28) states that "the benefits of a financial report will be reduced if the report is not available on time.

\section{c. Aggregation}

According to Ritonga, (2011: 33) aggregation is a summary of information by function, time period and decision model. Information by function will provide information regarding the outcome of a decision made by other units. Information by period of time is information that allows managers to assess their decisions from time to time. Information by decision is information provided to make decisions by analytical factors, such as inventory model analysis and cash flow discounted. In recent developments, information aggregation is a combination of functional and temporal information such as sales areas, cost-satisfied, production and marketing departments, and information generated specifically for formal decision models. Information is delivered in a more concise form, but it still includes important things that do not diminish the value of the information itself. The aggregated information will serve as a useful input in the decision-making process, as less time is required to evaluate it, thereby improving the efficiency of management work (Chia, 1995: 815).

\section{d. Integration}

An important aspect of organizational control is the coordination of the various segments within sub-organizations. Characteristics of Management Accounting Information Systems that assist coordination include target specifications that show the effect of segment interaction and information on the influence of decisions on the operation of all sub-units of the organization. Chia (1995) states that integrated information from management accounting systems can be used as a means of coordination between segments of sub-units and between sub-units. The complexity and interdependence of sub-units will be reflected in the integrated information of the management accounting system. The benefits of integrated information are perceived as important when managers are faced with situations in which decisions have to be impacted on the part

\section{Business Strategy}

Business is defined as all activities organized by people engaged in commerce (producers, traders, consumers, and industries where the company is located) in order to improve their standards and quality of life. (Husayn, 2015). Understanding the strategy there are several kinds as presented by experts in their respective books. According to Marrus (2011) strategy is defined as a process of determining the plans of top leaders that focus on the long-term goals of the organization, accompanied by the preparation of a way or effort how to achieve that goal.

According to Hamel and Prahalad (2014) strategy is an incremental (continuous improvement) and continuous action, and is based on the viewpoint of what future customers expect. Thus, strategy almost always starts from what can happen and not start from what happened. The occurrence of new market innovation speed and changes in consumer patterns require core competence. Companies need to seek competence to find core competencies in the business (Husein, 2015). 
INTERNATIONAL JOURNAL OF ACADEMIC RESEARCH IN BUSINESS AND SOCIAL SCIENCES Vol. 8, No. 7, July 2018, E-ISSN: 2222-6990 @ 2018 HRMARS

Business strategy is the art and science of composing, applying, and evaluating crossfunctional decisions that enable a company to achieve its goals. Strategic management is the process of setting organization goals, developing policies and planning to achieve those goals, and allocating resources to implement policies and plan the achievement of organizational goals (Husein Umar, 2015). Miles and Snow (2010) identify four types of business strategies that are often used by companies, namely:

a. Prospector. Companies belonging to this type of prospector strategy are companies that are constantly looking for new market opportunities by competing through new products and market development and experimenting with potential responses to emerging environmental trends, so competitors must always respond. Prospective companies place more emphasis on the flexibility of technology, the degree of routine, and the degree of mechanization in their various operational activities, so that it has a tendency to implement aggressive competitive strategy designs in order to remain a pioneer in certain products and market segments. Effectiveness is more important than efficiency, making it hard to find maximum profit, but always avoid low profitability. Usually compare the performance of the organization with the performance of its competitors.

b. Defender. Characteristics of companies that fall into this category tend to have less dynamic properties. The defender strategy is that if the company operates in a relatively stable production area, the offered product is limited compared to its competitors and the company rarely makes adjustments in the technology and structure or method of operation of the company and predictable direction of future changes. Thus, the company is more concerned with maintaining a certain portion of the market share of the whole market by creating certain products and services as well as the number of stable customers. Companies with the defender type maintain better attachment and stability with the environment than their competitors. Technological financing is done as efficiently as possible and efficiency is central to organizational performance.

c. Analyzer. Strategy analyzer is a combination of prospector and defender. The Company operates in two types of domains of relatively stable market products and keeps making changes. If in a stable area, the company will operate regularly and efficiently using previously formulated structures and processes. Changes are made by managers always paying close attention to their competitors in relation to ideas to be taken, then quickly adopting something that is most promising. Performance measurements are based on efficiency and effectiveness balance measurements. Companies tend to implement a balance strategy between activities undertaken to gain opportunities to expand market share of new products and services while maintaining relationships with existing customers and suppliers. The company's main focus in this category is on the one hand minimizing risks due to the utilization of outdated technology, while on the other hand the company seeks to earn profits by imitating the innovation of successful products and services (benchmarking).

d. Reactor. Reactor strategy is a corporate strategy whose top managers often accept the changes and uncertainties that occur within their organization, but do not respond effectively so that this type of company does not have a strategy to constantly adjust its information technology to the changing environment. Therefore, the company does not make adjustments, unless the environmental pressure is really strong.

\section{Performance}

Prawirosentono (2010: 120) mentions the performance, or performance is the work that can be achieved by a person or group of people within an organization, in accordance with the 
INTERNATIONAL JOURNAL OF ACADEMIC RESEARCH IN BUSINESS AND SOCIAL SCIENCES Vol. 8, No. 7, July 2018, E-ISSN: 2222-6990 @ 2018 HRMARS

responsibility and authority of each in an effort to achieve organizational goals. There is a close relationship between individual performance and organizational performance, in other words, when good employee performance then the possibility of organizational performance is also good.

As'ad, (2011: 48), writes that job performance or business performance is the result achieved by a person according to the size applicable to the work in question, as a level where the employee meets the specified job requirements. According to Dessler (2011: 268), performance analysis is verifying that there is a performance deterioration and determining whether this deterioration should be improved through training or through other means.

From the above quotation can be concluded that the performance is an achievement obtained a company or individual on a level where employees meet / reach the specified work requirements. To get a workforce that has a good performance performance assessment is necessary, because with a good assessment system, employees know what is expected by the company.

Performance is a description of the achievement of the implementation of an activity / program / policy in realizing the goals, objectives, mission and vision of the organization. The list of what to be achieved is contained in the formulation of the strategic (strategic planning) of an organization. In general, performance is an achievement achieved by the organization within a certain period

(Indra, 2006). Fitri and Syam (2002) define performance as an act of a person to meet expectations related to his function or a picture of the reaction of his work. Rustiana (2012) provides a definition of managerial performance as an individual performance perception of managers consisting of eight dimensions of activity, namely planning, investigation, coordination, supervision, staffing, negotiation, and representation. Juniarti and Evelyne (2013) mentioned that managerial performance is a measure of how effectively and efficiently managers have worked to achieve organizational goals. Mulyadi and Setyawan (2001) mentions the performance is the level of achievement of the implementation of an activity in realizing the targeted target.

Objective performance measurements are obtained directly from individual actions, as measured by subjective consideration of work. Performance measurement is needed to evaluate and determine the effectiveness of the actions managers perform. Performance measures can serve as a basis for making improvements to create better performance in the future. Performance data is collected during periodic operations. The data is reported to managers who supervise certain operational activities for the purpose of evaluating the progress of their performance. Performance is evaluated by comparing the results achieved with predetermined plans.

Mahoney et al (1963), what is meant by managerial performance is the performance of individual members of the organization in managerial activities, such as planning, investigation, coordination, supervision, staffing, negotiation and representation. Mulyadi (2010), managerial performance is a performance generated by a manager by mobilizing the talents and abilities and efforts of several others who are within the territory of his authority.

\section{Framework}

Effect of Management Accounting Information System Characteristics on Managerial Performance

Agbejule (2005) states that the characteristics of information in the form of broad scope, timeliness, aggretation, and integration can improve the performance of managers. Managers who have these characteristics are generally able to make better planning and achieve targets that have been established and able in terms of organizing, direction, and decision making. 
INTERNATIONAL JOURNAL OF ACADEMIC RESEARCH IN BUSINESS AND SOCIAL SCIENCES Vol. 8, No. 7, July 2018, E-ISSN: 2222-6990 @ 2018 HRMARS

Information is needed in decision making. Management requires adequate information for decision making. Sufficient information is information that has the characteristics of broad scope, timeliness, aggregation and integration of information required management in support of the best decision making. Good decision making will have an effect on managerial performance. Characteristics of a broad scope provides information about external and internal factors of the firm, economic and non-economic information, estimates of future events. Timeliness is a consideration in decision making before the information loses its ability to influence the decision. Aggregation information is required within the company, as it can prevent the possibility of over-loading the information. Integrated information reflects the coordination between sub-unit segments with each other. Integrated information is needed in decision making in organizations with a level of complexity and interdependence between higher sub-units. One of the products in a management accounting system is that management accounting information plays a role in helping to predict the possible consequences of various alternative actions that can be performed on various activities such as planning, controlling, and decision making. The characteristics of information available within the organization will be effective when it can support the information user or decision maker. Compatibility between information and the needs of decision makers will improve the quality of decisions to be taken that can ultimately improve managerial performance Juniarti and Evelyne (2013) mentioned that there is influence of information management accounting system characteristic which consist of broad scope, timeliness, aggregation, and integration can improve managerial performance. This statement corroborates the results of research conducted by Chia (1995). Managers who have information with these characteristics are generally able to make better planning and achieve the target set. Hypothesis used in this research are:

Ha1: Characteristics of management accounting information system has a positive effect on managerial performance.

\section{Effect of Management Accounting Information System Characteristics in Relation to Business Strategy on Managerial Performance}

Managerial performance is influenced by the interaction between management accounting information systems and business strategies. Business strategy is a moderator variable, moderator variable is a variable that has a strong dependency influence with the dependent variable relationship and independent variables that can change the initial relationship between independent and tied (Sekaran, 2012). The existence of conformity between business strategy and management accounting information system will result in higher managerial performance. Miles \& Snow (Faisal, 2010) classifies strategies into four types, namely prospector, analyzer, defender, and reactor. Companies with business prospector type of strategy have the possibility that the use of management accounting information system will produce more positive performance compared with companies using defender business strategy type (Miles and Snow, 2010). The prospector company continually monitors market opportunities and creates changes and uncertainties to respond to competitors. Performance is not only based on profit and efficiency but more important is to be a leader in product innovation (Faisal, 2006). The company needs a flexible and innovative structure so managers need external, non-financial, and forward-looking information for decision-making. Thus, broadscope information will be very useful in decision making (Abernethy \& Guthrie in Faisal, 2006). The defender company put more emphasis on the importance of standard cost and the realization of budget goals. Both information can be obtained from the information generated management accounting system. 
INTERNATIONAL JOURNAL OF ACADEMIC RESEARCH IN BUSINESS AND SOCIAL SCIENCES Vol. 8, No. 7, July 2018, E-ISSN: 2222-6990 @ 2018 HRMARS

To monitor information and maintain market share stability requires timeliness information (Palmer in Faisal, 2006). Ernawati, et al (2005) have examined the influence of business strategy on the information relationship of broad scope of management accounting system and managerial performance. Ernawati et al. (2005) found that for firms using business prospector strategies, the effect of broad scope information on accounting management systems would be more positive than firms using defender business strategies. From the above description, the hypothesis in this study are:

Ha2: The business strategy in relation to the characteristics of management accounting information system has a positive effect on managerial performance

Influence of Management Accounting Information System Characteristics in Relation to Task Uncertainty on Managerial Performance in Banking Companies in Aceh Province

Job uncertainty is an important variable that can affect the performance of information systems (Tjahjono, 2008). The higher the degree of task uncertainty, someone will be difficult to work well. Conversely, the lower the degree of uncertainty of a person's task will be easier in carrying out activities and the easier to improve performance (Tjahjono, 2008).

Chang (2003) found an influence between task uncertainty and information characteristics will have a positive effect on performance. The use of contingency theory in management accounting, prioritizing the concept of match in the level of conformity between contextual factors (contingency) with the design of management accounting system applied by the company so that will enable managers to improve their performance and further improve the company performance. Wiryana (2014) mentions that the interaction of task uncertainty that serves as a moderator variable with the characteristics of management accounting information systems have a positive and significant effect on managerial performance. Under conditions of high task uncertainty, managers require a wider management accounting information system to control day-to-day operations and solve unusual problems or events. when the need for management accounting information systems in case of task uncertainty is met then the performance of managers will increase. The scheme framework in this study can be seen in Figure 1

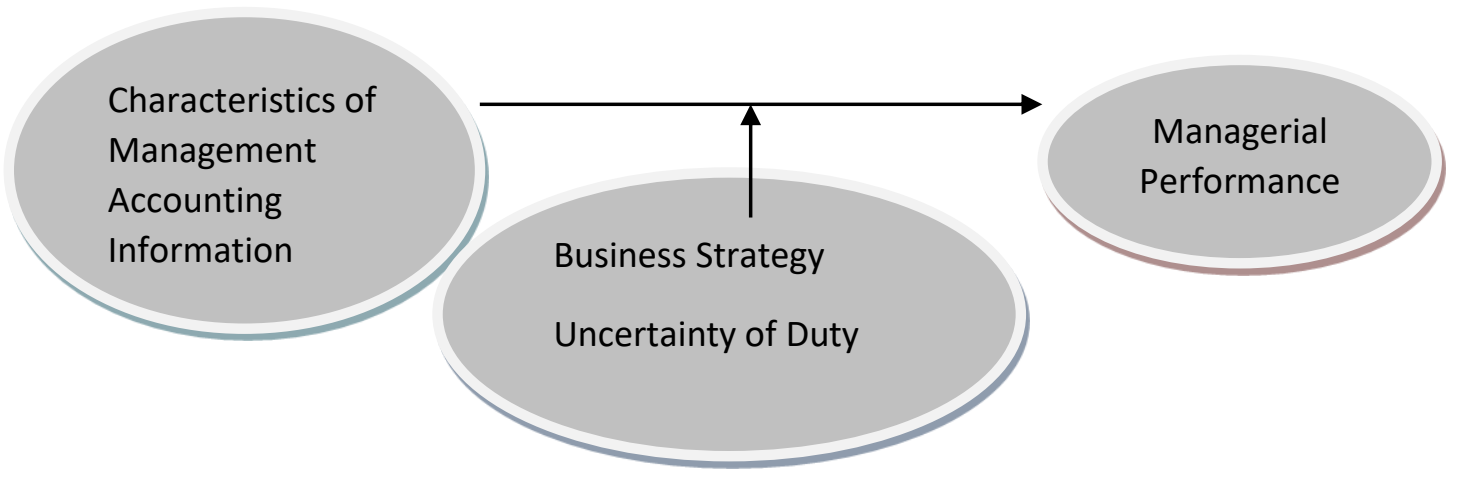

Figure 1 Thinking Framework Thought

Hypothesis

H1. Characteristics of management accounting information systems affect the managerial performance of Banking Companies in Aceh Province. 
INTERNATIONAL JOURNAL OF ACADEMIC RESEARCH IN BUSINESS AND SOCIAL SCIENCES

Vol. 8, No. 7, July 2018, E-ISSN: 2222-6990 (C) 2018 HRMARS

H2. Characteristics of management accounting information systems have an effect on managerial performance with business strategy moderation variable at Banking Company in Aceh Province

H3. Characteristics of management accounting information system effect on managerial performance with the variable of uncertainty of tasks at Banking Company in Aceh Province

\section{Research Methods}

To know the influence of management accounting information system characteristics to managerial performance with business model moderation variable and task uncertainty in banking company in Aceh Province using regression equation as follows:

$\mathrm{Y}=\mathrm{a}$ b1X1 b2X2 b3X3 b4X1X2 b5X1X3 ह́

Where :

$\mathrm{Y}=$ Performance

$\mathrm{a}=$ Constants

b1, b2, b3, b4, b5 = Regression Coefficients

$\mathrm{X} 1$ = Management Accounting Information System Characteristics

$\mathrm{X} 2$ = Business Strategy

$\mathrm{X} 3$ = Uncertainty of Duty

$\mathrm{X} 1, \mathrm{X} 2$ = Characteristics of management accounting information system with business strategy budgeting

$\mathrm{X} 1, \mathrm{X} 3$ = Interaction between information management system accounting characteristics with Task

Uncertainty

$\dot{\varepsilon}=$ Error Terms

RESULTS AND DISCUSSION

Classical Assumption Test Analysis

\section{a. Pengujian Normalitas}

Normality test is used to find out whether the distribution of research data of each variable has spread normally 


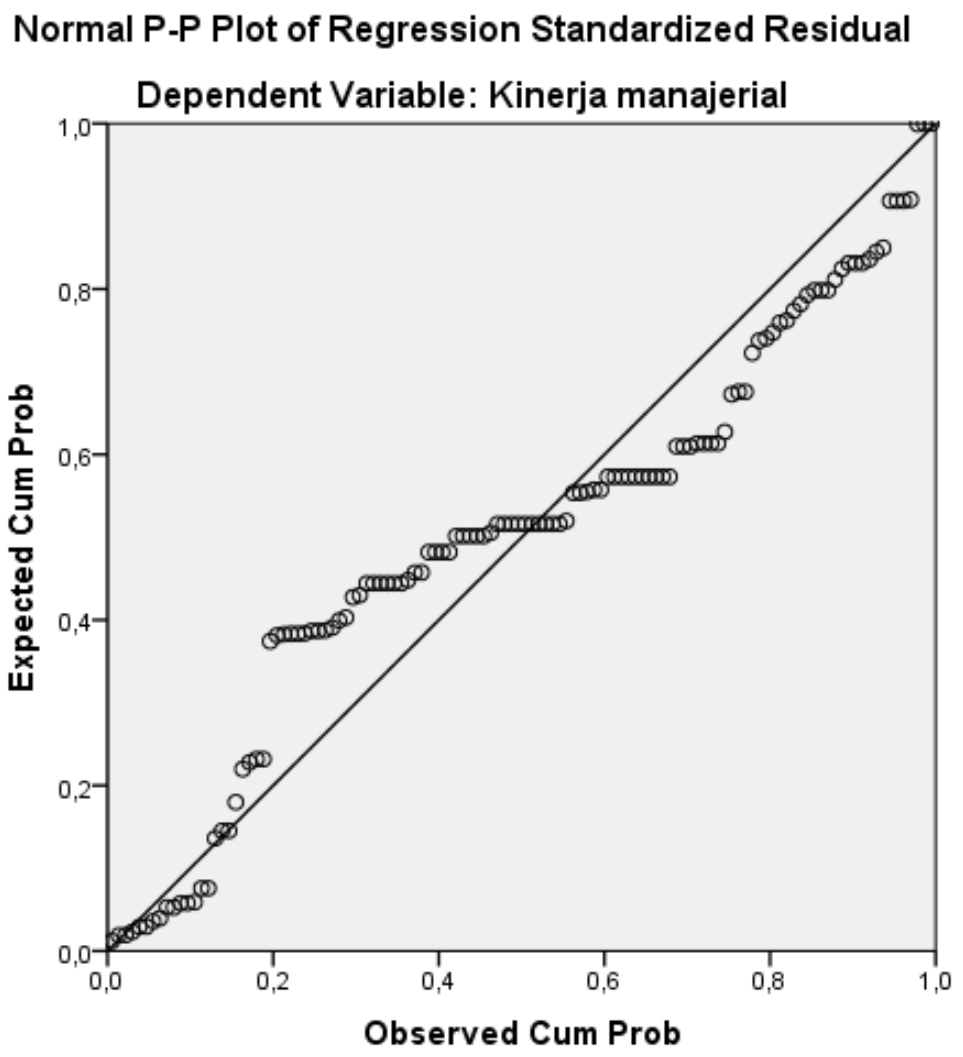

Figure 4.1: Normal P-P Plot of Regression Standarized

From the result of this research, it can be concluded that the data is normally distributed. b. Multicolinearity Testing

Gujarati (2001: 166) states to detect multicollinearity can be seen from the value of Pearson Corelation Matrix with Rule of Thumb if the value of correlation among the free variables is smaller than $\mathbf{0 . 8 0}$, then there is no multicollinearity. Multicolinearity occurs when there is a strong relationship between two or more in the independent variable.

Table 4.7

Correlations

\begin{tabular}{|c|c|c|c|c|c|c|}
\hline & $\mathbf{Y}$ & $\mathbf{X 1}$ & $\mathbf{X 2}$ & $\mathbf{X 3}$ & $\mathbf{X 1 X 2}$ & $\mathbf{X 1 X 3}$ \\
\hline $\mathbf{Y}$ & $\mathbf{1 , 0 0 0}$ & $\mathbf{0 , 7 7 2}$ & $\mathbf{0 , 7 6 4}$ & $\mathbf{0 , 7 5 6}$ & 0,777 & 0,768 \\
\hline $\mathbf{X 1}$ & 0,772 & 1,000 & 0,761 & 0,777 & 0,787 & 0,774 \\
\hline $\mathbf{X 2}$ & 0,764 & 0,761 & 1,000 & 0,756 & 0,772 & 0,763 \\
\hline $\mathbf{X 3}$ & 0,756 & 0,777 & 0,756 & 1,000 & 0,776 & 0,775 \\
\hline $\mathbf{X 1 X 2}$ & 0,777 & 0,787 & 0,772 & 0,776 & 1,000 & 0,787 \\
\hline $\mathbf{X 1 X 3}$ & 0,768 & 0,774 & 0,763 & 0,775 & 0,787 & 1,000 \\
\hline
\end{tabular}

Source: Primary Data, 2017 (Processed)

In this study, the matrix correlation value for all independent variables is smaller than 0.80 , thus it can be concluded that the variables in this study did not occur multicollinearity, so as not to violate the classical assumption. For more details multicollinearity testing can be seen in Table 4.7. 
INTERNATIONAL JOURNAL OF ACADEMIC RESEARCH IN BUSINESS AND SOCIAL SCIENCES

Vol. 8, No. 7, July 2018, E-ISSN: 2222-6990 (C) 2018 HRMARS

\section{c. Autocorrelation Testing}

To find out if autocorrelation exists in a particular event is to use the Durbin Watson test. The basis of decision making in the autocorrelation test is if DU $\angle D W<4$-du then there is no autocorrelation either positive or negative. The results showed that the value of DW $=2.077$ greater than DU value is 1.6061 or $\mathrm{DW}=2.077<$ from 4-DU $=2,3939$ it can be concluded in this study there is no autocorrelation.

\section{d. Heteroscedasticity}

Heteroscedasticity is if not obey the assumption in multiple regression, that is the variance obtained is the same (constant), from result of research obtained there is no heterokedastisitas where its variance is not constant, for more details can be seen in Figure 4.2.

scatterplot

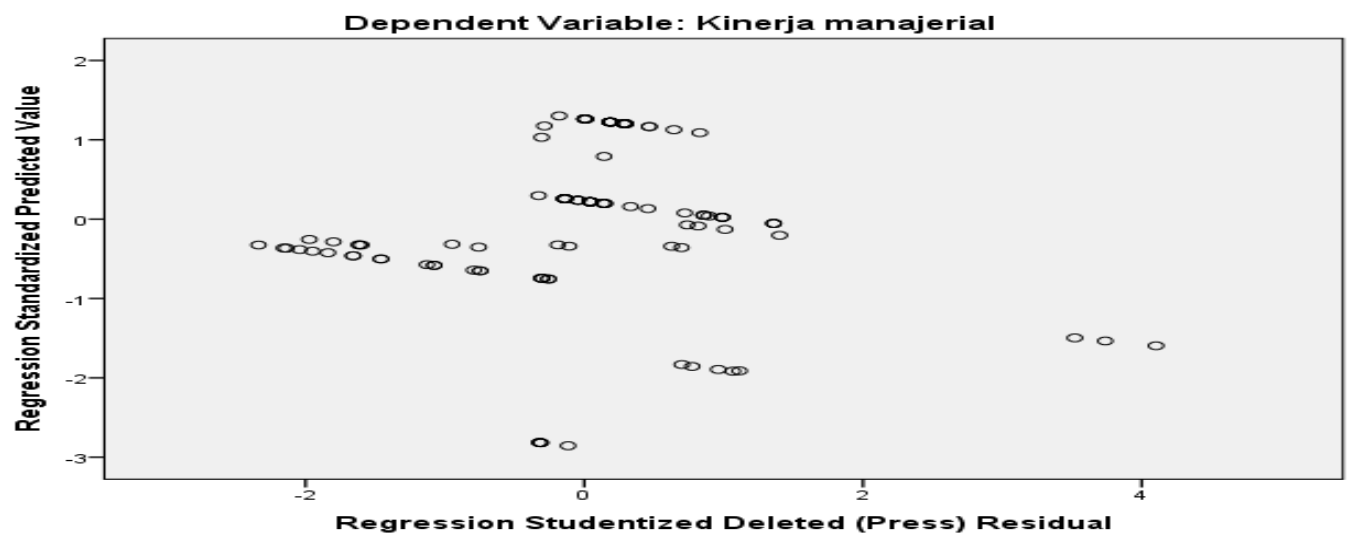

Figure 4.2:

Hetroskedatisitas

\section{Hypothesis Testing Results}

To know the influence of management accounting information system characteristic, job uncertainty and business strategy toward managerial performance in Banda Aceh City will be tested by using multiple linear regression. The results of his research can be seen in Table 4.8 .

Table 4.8

Regression Calculation Result

\begin{tabular}{|c|c|c|c|}
\hline Variable & $\begin{array}{c}\text { Koefisien } \\
\text { Regression }\end{array}$ & T-account & Signifikansi \\
\hline Constant & 0,112 & 0,936 & 0,351 \\
\hline $\mathrm{X} 1$ & 0,377 & 3,808 & 0,024 \\
\hline $\mathrm{X} 2$ & 0,487 & 4,200 & 0,002 \\
\hline X3 & $-0,479$ & $-3,060$ & 0,003 \\
\hline $\mathrm{X} 1 \mathrm{X} 2$ & 0,228 & 3,816 & 0,031 \\
\hline $\mathrm{x} 1 \times 3$ & 0,809 & 2,925 & 0,011 \\
\hline $\begin{array}{l}R=0,979 \\
R^{2}=0,959 \\
A D J R^{2}=0,957\end{array}$ & & & \\
\hline \multicolumn{4}{|c|}{$F=375,248 \quad S I G=0,00$} \\
\hline
\end{tabular}

Source: Primary Data, 2017 (Processed) 
From the research results obtained the final equation estimator that is: $Y=0.1120 .377 X 1$ $0.487 \times 2-0.479 \times 30.228 \times 1 \times 20.809 \times 1 \times 3$. The equation implies that:

- Constants of 0.112 , meaning that if the variable characteristics of management accounting information systems, task uncertainty, business strategy, interaction characteristics management accounting information system with business strategy and interaction between information management accounting system characteristics with task uncertainty is considered constant then managerial performance of 0.112 percent.

- If the variable characteristics of management accounting information system changes by 1 percent it will affect the increased managerial performance of 0.337 percent assuming the variable of task uncertainty, business strategy, interaction characteristics management accounting information system with business strategy and interaction between information characteristics management accounting system with task uncertainty is considered fixed

- If the variable of business strategy has increased by 1 percent, it affects the managerial performance increase of 0.487 percent assuming the variable characteristics of management accounting information system, task uncertainty, interaction characteristics management accounting information system with business strategy and interaction between information management accounting system characteristics with uncertainty task is considered fixed.

- If the variable of task uncertainty experienced an increase of 1 percent, it affects the decreased managerial performance by 0.479 percent assuming the variable characteristics of management accounting information system, business strategy, interaction characteristics management accounting information system with business strategy and interaction between information management accounting system characteristics with uncertainty task is considered fixed.

- If the variable characteristics of management accounting information system with business strategy has increased by 1 percent it will affect the increase in managerial performance of 0.228 percent assuming the variable characteristics of management accounting information systems, task uncertainty, business strategy and interaction between information management accounting system characteristics with uncertainty task is considered fixed.

- If the variable characteristics of management accounting information systems with task uncertainty increased by 1 percent it will affect the increased managerial performance of 0.809 percent assuming the variable characteristics of management accounting information systems, task uncertainty, business strategy and interaction characteristics management accounting information system with business strategy considered fixed.

- The correlation coefficient (R) of 0.979 which illustrates that the characteristics of management accounting information system, task uncertainty and business strategy have closeness relationship to managerial performance of 97.9 percent.

- Adj R2 coefficient worth 0,957 indicate that variation of management accounting information system characteristic, task uncertainty and business strategy influence to variation of managerial performance equal to $95,7 \%$ and the rest $4,3 \%$ influenced by other variable outside this research model.

\section{Hypothesis Testing Results Simultaneously}

Simultaneous test conducted to know how the influence of independent variables on the dependent variable simultaneously, simultaneous test shows the influence of independent variables together to the dependent variable. From the research result, the value of F-count is 375,248 bigger 
INTERNATIONAL JOURNAL OF ACADEMIC RESEARCH IN BUSINESS AND SOCIAL SCIENCES Vol. 8, No. 7, July 2018, E-ISSN: 2222-6990 @ 2018 HRMARS

than F-table value $=2,135$ meaning management accounting information system characteristic, task uncertainty, business strategy and interaction characteristic of management accounting information system with business strategy and interaction between information characteristic of management accounting system with task uncertainty together affect the managerial performance.

\section{Hypothesis Testing Results Partially}

Evidence of characteristic variable of management accounting information system and business strategy toward managerial performance in Banda Aceh City is done partially test by itself. The results obtained are as follows:

- For the variable characteristics of management accounting information system obtained t-count value of 3.808 greater than the value of $t$-table $=1.8954$ means the variable characteristics of management accounting information system partially significant effect on managerial performance.

- For business strategy variables obtained $\mathrm{t}$-count value of 4.200 is greater than the value of $\mathrm{t}$-table $=$ 1.8954 means meaning business strategy variables partially affect the managerial performance.

- For task uncertainty variable obtained t-count value of 3.060 greater than the value of $\mathrm{t}$-table $=$ 1.8954 means that the variable of task uncertainty in partial effect on managerial performance- For the interaction variable characteristics of management accounting information system with business strategy obtained $t$-count value of 3.816 greater than the value of $t$-table $=1.8954$ means meaning interaction variable management accounting information system with business strategy partially influence on managerial performance.

- For the interaction variable between information management accounting system characteristics with task uncertainty obtained t-count value of 3.816 is greater than the value of $t$-table $=1.8954$ means that the interaction variable between the characteristics of management accounting system information with the task uncertainty partially affect the managerial performance .

\section{Discussion}

Effect of Management Accounting Information System Characteristics on Managerial Performance

Characteristics of management accounting information system significant effect on managerial performance, this finding is in line with research conducted by Agbejule (2005) states that the characteristics of information in the form of broad scope, timeliness, aggretation, and integration can improve manager performance. Managers who have these characteristics are generally able to make better planning and achieve targets that have been established and able in terms of organizing, direction, and decision making.

On the other hand, these findings are also in line with Juniarti and Evelyne (2013) mentioned that the characteristics of management accounting information systems consisting of broad scope, timeliness, aggregation, and integration can improve managerial performance. This statement corroborates the results of a study also conducted by Chia (1995). Managers who have information with these characteristics are generally able to make better planning and achieve the targets that have been set so that will improve performance. This finding is also in line with research Wiryana (2014) said that the characteristics of management accounting information system has a positive and significant effect on managerial performance. 
INTERNATIONAL JOURNAL OF ACADEMIC RESEARCH IN BUSINESS AND SOCIAL SCIENCES Vol. 8, No. 7, July 2018, E-ISSN: 2222-6990 @ 2018 HRMARS

\section{The Influence of Business Strategy on Managerial Performance}

Business strategy has a significant effect on managerial performance Yuristisia (2011) mentioned that business strategy has an effect on managerial performance. The increase in managerial performance occurs because firms in entering increasingly fierce competition will apply competitive strategies to survive. Business strategies implemented by the company will certainly require the company to provide the information needed to achieve the chosen business strategy. Any business strategy chosen by the company will necessarily require different levels of information that will ultimately improve performance. This finding is also in line with research Wiryana (2014) said that business strategy has a positive and significant effect on managerial performance.

The Influence of Job Uncertainty on Managerial Performance Task uncertainty has a significant effect on managerial performance. This finding is in line with Tjahjono's research, (2008) said task uncertainty is an important variable that can affect the performance of information system, the higher degree of task uncertainty, someone will be difficult to work well. Conversely, the lower the degree of uncertainty of a person's task will be easier in carrying out activities and increasingly easy to improve performance. This finding is also in line with research Wiryana (2014) said that task uncertainty has a positive and significant effect on managerial performance.

\section{Effect of Management Accounting Information System Characteristics in Relation to Business Strategy on Managerial Performance}

Interaction characteristic of management accounting information system with business strategy have significant effect to managerial performance. This finding is in line with the research conducted by Sekaran, (2012) that managerial performance is influenced by the interaction between management accounting information system and business strategy. Business strategy is a moderator variable, moderator variable is a variable that has a strong dependency influence with the dependent variable relationship and independent variables that can change the initial relationship between independent and dependent variables. The existence of conformity between business strategy and management accounting information system will result in higher managerial performance. Miles \& Snow (Faisal, 2010) classifies strategies into four types, namely prospector, analyzer, defender, and reactor. Companies with business prospector type of strategy have the possibility that the use of management accounting information system will produce more positive performance compared with companies using defender business strategy type (Miles and Snow, 2010). The prospector company continually monitors market opportunities and creates changes and uncertainties to respond to competitors. Performance is not only based on profit and efficiency but more important is to be a leader in product innovation (Faisal, 2006). Ernawati, et al (2005) have also examined the influence of business strategy on the information relationship of broad scope of management accounting system and managerial performance. Ernawati et al. (2005) found that for firms using business prospector strategies, the effect of broad scope information on accounting management systems would be more positive than firms using defender business strategies. 
INTERNATIONAL JOURNAL OF ACADEMIC RESEARCH IN BUSINESS AND SOCIAL SCIENCES Vol. 8, No. 7, July 2018, E-ISSN: 2222-6990 @ 2018 HRMARS

\section{Influence of Management Accounting Information System Characteristics in Relation to Task Uncertainty on Managerial Performance in Banking Companies in Aceh Province}

The interaction between information management accounting system characteristics with task uncertainty has a significant effect on managerial performance. This finding is also in line with Chang (2003) who found that the influence between task uncertainty and information characteristics will have a positive effect on performance. The use of contingency theory in management accounting, prioritizing the concept of match in the level of conformity between contextual factors (contingency) with the design of management accounting system applied by the company so that it will enable managers to improve their performance and further improve the performance of the company.

On the other hand also in line with research Wiryana (2014) mentions that the interaction of task uncertainty that serves as a moderator variable with the characteristics of management accounting information systems have a positive and significant effect on managerial performance. Under conditions of high task uncertainty, managers require a wider management accounting information system to control day-to-day operations and solve unusual problems or events. when the need for management accounting information systems in case of task uncertainty is met then the performance of managers will increase

\section{Conclusion}

- Characteristics of management accounting information systems have a positive and significant effect on managerial performance.

- Business strategy has a significant and positive effect on managerial performance.

- Job uncertainty has significant and negative impact on managerial performance

- Interaction characteristics of management accounting information system with business strategy have a significant and positive effect on managerial performance

- Interaction between information management system accounting characteristics with task uncertainty have a significant and positive effect on managerial performance.

\section{Suggestions}

- Company samples can be done to other companies with different fields such as hotels, construction services, tradding companies and so on.

- Further research is also important to consider other contingency variables, such as job satisfaction, organizational commitment, and motivation as a moderator variable.

- Related to the results of the research will be the variables of decentralization can be done further research with the selection of samples on companies with good organizational culture such as American companies and European companies, so it can be seen the consistency of research results

\section{References}

Anthony, N., Robert \&, Govindarajan, V. (2002). Management Control System. Jakarta: Salemba Empat.

As'ad, M. (2011). Phisikologi Industri. Yogyakarta: Liberty. 
INTERNATIONAL JOURNAL OF ACADEMIC RESEARCH IN BUSINESS AND SOCIAL SCIENCES Vol. 8, No. 7, July 2018, E-ISSN: 2222-6990 @ 2018 HRMARS

Atkinson, A. A.. RJ. Banker, R.S. Kaplan dan S.M. Young (2015). Management Accounting Englewood Cliffs, New Jersey, Prentice-Hall.

Chang, R.-D., Chang, Y.-W., \& Paper, D. (2003). The effect of task uncertainty, decentralization and AIS characteristics on the performance of AIS: an empirical case in Taiwan. Information \& Management. Vol 40 No 8: 691-703.

Chenhall, R. H., Deigan, M. (2011). The Consequences of Customization on Management Accounting System Design, MIS Quarterly. Vol.29 No 11: 299-324.

Chia, Y. M. (1995). Decentralization, Management Accounting System (MAS) Information Characteristics and Their Interaction Effects on Managerial Performance: A Singapure Study. Journal of Business Finance and Accounting. Vol 3 No 5: 811-830.

Croteau, L. (2003). Create an Empowering Environment," Personnel Journal, September. Vol 6 No 7: 28-36.

Dessler, G. (2011) Manajemen Personalia. Terjemahan Agus Darma, Penerbit Erlangga, Jakarta.sher.

Efendi, D. (2007). Pengaruh Informasi Akuntansi dan Ketidakpastian Tugas terhadap Kinerja Manajer. Jurnal Akuntansi dan Investasi Vol. 8 No. 2: 137-146.

Ernawati, Suranta, S., \& Syafiqurrahman, M. (2005). Pengaruh strategi bisnis dan ketidakpastian lingkungan terhadap hubungan antara informasi broad scope sistem akuntansi manajemen dan kinerja manajerial. Perspektif. Vol 10 No 2: 195-207.

Fitri, F., \& Syam, B. Z. (2002). Pengaruh sistem akuntansi manajemen dan ketidakpastian lingkungan terhadap kinerja manajer. Jurnal Manajemen dan Bisnis. Vol 4 No1: 57-66.

Faisal. (2010). Analisis pengaruh intensitas persaingan dan variable kontekstual terhadap penggunaan informasi system akuntansi manajemen dan kinerja unit bisnis dengan pendekatan partial least square [On-line] Available http://info.stieperbanas.ac.id/makalah/KAMEN11. pdf?PHPSESSID=e5be9a8dd7a468f304bcc28815922d23

Gul, F. (1991). The ElTecls of Management Accounong Systems and Environmemal Uncerrauq on Small The ElTecls of Management Accounong Systems and Environmemal Uncerrauq on SmallBusmess Managers Performance. Accounting and Butlness Research: 57-61.

GuL, F. A., \& Chia, Y. M. (1994). The Effects Of Management Accounting System, Perceived Environmental Uncertainty And Decentralization on Managerial Performance: A Test Of Three Way Interaction. Accounting Organizations And Society Vol. 19, 413-426.

Hirst, M. K. (2011). Accounting Information and The Evaluation of Subordinate performance; A Situasional Approach. The Accounting Review. Vol LVI: 771-784.

Ikatan Akuntansi Indonesia, (2011). Standar Akuntansi Keuangan, Buku Tiga. Yogyakarta: Salemba empat.

Jusoh, R. (2012). Environmental uncertainty, performance, and the mediating role of balanced scorecard measures use : evidence from Malaysia. International Review of Business Research Papers. Vol 4 No2: 116-135. 
INTERNATIONAL JOURNAL OF ACADEMIC RESEARCH IN BUSINESS AND SOCIAL SCIENCES Vol. 8, No. 7, July 2018, E-ISSN: 2222-6990 @ 2018 HRMARS

Mangkuprawira, S (2011). Manajemen Sumber Daya Manusia Strategik. Cetakan Kedua. Ghalia Indonesia. Jakarta.

Mahoney, T., Jerdee, T., \& Caroll, S. (1963). Development of Managerial Performance: A Research Approach. Cincinnati: South Western Publishing.

Mia, L. (1993). The Role Of MAS Information In Organizations; An empirical study. British Accounting Review: 269-285.

Miles, R. E., \& Snow, C. C. (2010). Designing Strategic Human Resources Systems. Business Strategies: $36-52$.

Milgrom, P., \& Roberts, J. (2010). The Economics Modern manufacturing : Technology, Strategy, And Organization. The American Economic Review. Vol. 80, No. 3: 511-528.

Mulyadi. (2010). Akuntansi Manajemen Konsep Manfaat dan Rekayasa. Jakarta: Salemba Empat. Munie (2009). Manajemen Personalia. Jakarta: PT Rineka Cipta.

Nyoman Desak Sri Werastuti (2015). Faktor-Faktor yang Mempengaruhi Kinerja Pemerintah daerah Kabupaten Bangli. Jurnal Penididikan Ganesha Jurusan Akuntansi. Vol 3 No:1.5-17.

Paylosa Fanny (2014). Pengaruh Strategi Bisnis dan Desentralisasi Terhadap Hubungan Antara Pemanfaatan Informasi Sistem Akuntansi Manajemen dan Kinerja Manajerial (Studi Empiris Pada Perusahaan Jasa Perhotelan di Kota Padang dan Bukittinggi). Thesis. Program Studi Akuntansi Fakultas Ekonomi Universitas Negeri Padang.

Prawirosentono (2010). Manajemen Sumber Daya Manusia. Penerbit Bumi Aksara, Solechan, A., \& Setiawati, I. (2009). (The Influence Of Management Accounting System (MAS) Characteristic. Fokus Ekonomi. Vol. 4 No 1: 64-74.

Syam, F., Lilis, M. (2006). Sistem Akuntansi Manajemen, Persepsi Ketidakpastian Lingkungan, Desentralisasi, dan Kinerja Organisasi. Jurnal Simposium Nasional Akuntansi 9 Padang, Agustus 2006.

Tjahjono, H. K., \& Stevany, H. A. (2008). Pengaruh Partsisipasi Dan Ketidakpastian Tugas Dalam Pengembangan Sistem Informasi Manajemen Pada Kinerja Sistem Informasi. Universitas Muhammadiyah Yogyakarta: 1-18.

Sekaran, U. (2012). Research Methods for Business. New York : John Wiley \& Sons Inc. Soeprihanto, J. (2010) Manajemen Sumber Daya Manusia II. Jakarta: Karunia, Universitas Terbuka. Yuristisia, C. (2011). Pengaruh Sistem Akuntansi Manajemen Terhadap Kinerja Manajerial Dengan Variabel Moderasi Strategi Bisnis, Perceived Environmental Uncertainty (PEU), Dan Desentralisasi (Case Study: Perusahaan Manufaktur Di Prov. JAMBI). Jurnal Ekonomi Bisnis. Vol 3 No 2: 42-49. 